University of Warwick institutional repository

This paper is made available online in accordance with

publisher policies. Please scroll down to view the document

itself. Please refer to the repository record for this item and our

policy information available from the repository home page for further information.

To see the final version of this paper please visit the publisher's website. Access to the published version may require a subscription.

Authors: Diane Stone

Article Title: Transfer agents and global networks in the 'transnationalization' of policy

Year of publication: 2004

Link to published version:

http://dx.doi.org/10.1080/13501760410001694291

Publisher statement: None 


\title{
Transfer Agents and Global Networks in the \\ ‘Transnationalisation’ of Policy
}

\section{Diane Stone}

\begin{abstract}
This paper focuses on the role of international actors in policy/knowledge transfer processes to suggest that a dynamic for the transnationalisation of policy results. The paper seeks to redress the tendency towards methodological nationalism in much of the early policy transfer literature by bringing to the fore the role of international organisations and non-state actors in transnational transfer networks. Secondly, attention is drawn to 'soft' forms of transfer - such as the spread of norms - as a necessary complement to the hard transfer of policy tools, structures and practices and in which non-state actors play a more prominent role. Thirdly, transnational networks are identified as an important vehicle for the spread of policy and practice not only cross-nationally but in emergent venues of global governance.
\end{abstract}

Keywords: global policy, international organisation, networks, non-state actors, policy transfer, social learning. 


\section{Introduction}

This paper focuses on the role of international actors in policy/knowledge transfer processes to suggest that a dynamic for the transnationalisation of policy results. International actors are taken to mean (i) international organisations; (ii) states and (iii) non-state actors. Policy transfer is understood as a process by which 'knowledge about how policies, administrative arrangements, institutions and ideas in one political setting (past or present) is used in the development of policies, administrative arrangements, institutions and ideas in another political setting' (Dolowitz \& Marsh, 2000: 5; my emphasis). Policy transfer can involve a number of processes. The objects of transfer can include (i) policies, (ii) institutions, (iii) ideologies or justifications, (iv) attitudes and ideas, and (v) negative lessons (Dolowitz, 1997). Transfer can take place across time, within countries and across countries. There are different degrees of transfer: straight-forward copying of policy, legislation or techniques as well as various forms of emulation, synthesis and hybridisation, and inspiration (Dolowitz \& Marsh, 1996: 351).

The aspirations of this paper are three fold. Firstly, with its focus on international actors the paper helps redress the tendency towards methodological nationalism in much of the early public policy transfer literature. International transfers of policy and practice do not always occur in a simple bilateral exchange between sovereign states but can be complemented and/or by-passed by transnational transfer networks. Few studies have addressed the key role of international organisations in policy transfer (but see Ogden, Walt \& Lush, 2003). Secondly, drawing on some international relations (IR) literature, the argument that transfer is likely to be more effective where learning has also taken place is advanced. Attention is drawn to 'soft' forms of transfer such as the spread of norms and knowledge - as a necessary complement to the hard transfer of policy tools, structures and practices. Learning can make the difference between successful transfers as opposed to inappropriate, uninformed or incomplete transfer. The public policy literature has tended to concentrate on the transfer of 'knowledge' - usually of a codified variety 
- as well as policy instruments and practices whereas the IR literature has been stronger on the diffusion of norms that can promote learning and building of consensus. Thirdly, transnational networks are identified as an important vehicle for the spread of policy not only cross-nationally but in emergent venues of global governance. Accordingly, whilst this paper is planted in the public policy tradition, it seeks some synthesis with the IR literature, especially that relating to global public policy networks, epistemic communities and transnational advocacy networks.

The paper is structured into four parts. The next section provides a general overview of 'diffusion', 'transfer', 'convergence' and 'learning' and some absences in the policy transfer literature. The third section draws upon empirical material to outline the diverse transfer activities of states, international organisations and non-state actors and to highlight some of the dilemmas and contradictions in the process. The fourth and final section draws attention to collaborative pursuit of transfer via policy/knowledge networks and consequences for global governance.

\section{Policy Transfer/Diffusion, Convergence and Learning.}

Policy transfer studies were originally developed in the US as a means to explain the adoption of policy and spread of diffusion throughout this federal system. Diffusion has been defined as "the process by which an innovation is communicated through certain channels over time among members of a social system” (Berry and Berry, 1999: 171). Diffusion describes a trend of successive or sequential adoption of a practice, policy or programme.

The 'diffusion' literature suggests that policy percolates or diffuses; something that is contagious rather than chosen. It connotes spreading, dispersion and dissemination of ideas or practices from a common source or point of origin. Four forces may create diffusion patterns:

1. A national communication network among state officials;

2. States are influenced by geographically proximate neighbouring states; 
3. Leader states pioneer the adoption of a policy that 'laggard' states subsequently follow;

4. National government is a vertical influence for emulation (Berry \& Berry, 2000: 172-78).

This perspective posits incremental changes in policy. The strength of the diffusion approach has been to generate robust results as to which states are likely to adopt innovations; the larger, more industrial and economically prosperous. A limitation is that it has little to say about how policies or practices are altered during processes of adoption (Orenstein, 2003: 174). By identifying patterns of policy adoption, the approach has neglected the political dynamics involved in transfer. Diffusion approaches exhibit a fascination with the process and the conditions for transfer rather than the content of new policies. While national decision-making can be influenced by diffusion, policy innovations elsewhere are not sufficient condition for another jurisdiction to adopt the same policy. The determinants of policy arrangements can include factors that are internal to a system more so than external factors; such as the changing dynamics of political interests and the socio-historical make-up of a polity.

The strength of the policy transfer literature has been to focus on decision-making dynamics internal to political systems and to address the role of agency in transfer processes. Indeed, the discussion in this paper emphasises the logic of choice in selection of policy ideas, the interpretation of circumstances or environment and (bounded) rationality in imitation, copying and modification by decision makers. However, transfers can be either voluntary or coercive or combinations thereof (Dolowitz and Marsh, 2000: 13-17). Terms such as ‘lesson-drawing’ (Rose, 1993) and 'systematically pinching ideas' (Schneider \& Ingram, 1988) portray transfer as a voluntary and somewhat rational activity. Other terms emphasise compulsory conformity; that is: 'penetration’ (Bennett, 1991) and 'external inducement' (Ikenberry, 1990). 'Policy transfer' is directly concerned with the contested politics of who gets what policy. 
Parallel to the burgeoning literature in the field of public policy, in political economy there is strong interest in convergence, especially from a new institutionalist perspective. This school suggests that transfer is more the outcome of structural forces. That is, driven by industrialisation, globalisation or regionalisation forcing a pattern of increasing similarity in economic, social and political organisation between countries. Where transfer attends to the conscious spread of policies and ideas between countries, convergence represents an important counter-factual proposition. Those in this school challenge the logic of choice and "have adopted a processual perspective which goes beyond the mechanical transfer model” (Radaelli 2000). The 'new institutionalism' views behaviour as being led by organisations and institutions through processes of institutional iso-morphism. This approach emphasises entrenched 'path dependencies' and the taken-for-granted aspects of political life where actors follow rules, shared interpretations, schema and meanings.

Approaches to convergence 'diverge on whether the structural driving force is economic or ideational, and whether states retain agency in the face of globalization or are dominated by structural determinants' (Drezner, 2001: 55). It would require another paper to engage with this debate. However, the approach here is not structurally deterministic and greater emphasis is given to the force of knowledge and of agency. Agent centred approaches do not dismiss structural forces but suggest that in varying degree, states and organisations can mediate these dynamics (Orenstein, 2003). Path dependencies may be overcome, in some instances, by powerful transnational forces. Convergence is not necessarily an outcome of policy transfer. Especially when negative lessons are drawn from experience elsewhere and contribute to divergence and/or modifications. The policy transfer literature also allows us to see the possibilities for convergence around broad policy objectives and principles but scope for divergence with regard to the instruments adopted, type of legislation or institutional modes of policy control/delivery. 
Consequently, some have portrayed policy transfer or emulation as a form of learning (Studlar, 2004).

Indeed, transfers of ideas or programmes are sometimes underpinned by deeper and prior process of learning. Here, the emphasis is on cognition and the redefinition of interests on the basis of new knowledge which affects the fundamental beliefs and ideas behind policy approaches (Hall, 1993). Theoretically, learning could just as likely be a mechanism for policy innovation or termination as well as policy transfers.

The concept of learning has been subject to numerous interpretations and criticisms in public policy (Bennett \& Howlett, 1992: 277), in comparative politics (Blyth, 2002) and international relations (Checkel, 1997). Richard Rose in his analysis of lesson-drawing suggests learning occurs via transnational 'epistemic communities’ (Haas \& Haas, 1995). For Paul Sabatier (1991), policy oriented learning occurs within advocacy coalitions. Peter Hall’s model of different orders of 'social learning' and paradigm shift is also influential. Policy learning occurs when policy-makers adjust their cognitive understanding of policy development and modify policy in the light of knowledge gained from past policy experience. Policy learning may result in a more coherent transfer of ideas, policies and practices whereas mere copying may well be ad hoc and piece-meal. Policy co-ordination and/or implementation is more likely to result when there is a reasonably wide consensus of the desirability of introducing policy lessons among actors inside and outside government.

Learning can lead to the development of 'consensual knowledge' by specialists and epistemic communities about the functioning of state and society but which is also accepted as valid by decision-making elites. When consensual knowledge is developed at a transnational level, the potential exists for the exchange of ideas providing impetus for policy transfer. 
Learning via regional or global networks helps promote an 'international policy culture', but it is not automatically the case that learning will institutionalise in international organisations or in national governments. Learning is uneven and imperfect across different actors within a policy network. Certain actors may have a greater capacity for learning whereas others may adopt lessons for symbolic purposes or as a strategic device to secure political support rather than as a result of improved understanding.

Consequently, learning can be of different 'orders'; shallow, tactical or instrumental learning as opposed to deeper social or policy learning. An international consensus may prevail on 'best practice' but local political realities may mean that this consensus cannot take root in policy development. Political and bureaucratic interests are constrained by electoral considerations, issues of feasibility, funding shortfalls, war or famine that prevent 'harder' institutional forms of transfer. Ascertaining the kind of learning and where or with whom it is taking place can provide understanding of the kind of policy change taking place as well as the possible effectiveness of that change. In short, there may be transfer of policy knowledge but not a transfer of policy practice. Accordingly, the next section of the paper suggests that the soft transfer of norms and knowledge is a necessary but not sufficient condition for learning in conjunction with transfer.

\section{Non-State Transfers, State-led Exports and International Policy Inducers.}

Research remains weak in the consideration of global, international and transnational structures, and whether policy transfer has become more widespread in recent decades (Evans \& Davies, 1999; Ogden, Walt \& Lush, 2003). The literature has focused on lessons and policy transfers between nation-states with an implicit tendency to assume a bilateral relationship. The policy transfer metaphor implies a direct exchange process between exporting and importing countries. However, there can be transfer agents that are not based in or identified with either the 
importing or exporting jurisdiction but which facilitate the exchange between a number of polities. Rather than bilateral horizontal transfers between states, policy transfers can occur vertically between states and international organisations or between transnational non-state actors. It is also possible to learn from more than one jurisdiction at a time, and to take away a multiplicity of lessons. It results in selective borrowing that leads to hybrids and adaptive innovation to make policy development better fit local conditions.

The policy literature is focused on the state. Accordingly, there has been a tendency towards 'methodological nationalism'; that is, a focus on dynamics within the nation-state and comparison of such sovereign units. Importantly, transfer can also be facilitated by organisations outside and between the state. In other words, policy transfer is just as likely to be achieved by mechanisms embedded in markets and networks as in the hierarchies of the state. The role of business in standards setting is well established. In the field of environmental governance, especially Europe, both green and business interest groups have played prominent roles in the advocacy and dissemination of voluntary agreements, ecolabels, or ecological tax reforms (Jörgens, 2000).

A further anomaly in the literature concerns the agents of, and actors involved in, transfer. The emphasis has been on the role of official agencies in such processes; that is, bureaucrats, politicians and government experts. However, the agents of lesson drawing and policy transfer are a much broader category of individuals, networks and organisations. Key actors in the mechanics of policy transfer are international organisations and non-state actors such as interest groups and NGOS, think tanks, consultant firms, law firms and banks. These non-state actors have been shown to have considerable agenda setting influence when they function as part of 'transnational advocacy networks' (TANs - see Keck \& Sikkink, 1998). Recognition of non-state and international organisation roles complicates understanding of policy transfer processes beyond 
that of simple bilateral relationships between importing and exporting jurisdictions to a more complex multilateral environment. It draws attention to the transnationalisation of policy via three sets of actors: states, international organisations and non-state sectors. These 'global policy advocates’ are ‘driving policy diffusion’ (Orenstein, 2003: 188).

\section{State Agencies of Transfer}

The Centre for Management and Policy Studies (CMPS) is a unit attached to the British Cabinet Office. CMPS promotes a 'lesson-drawing' dynamic within the British civil service. It has arranged seminars, produced documents and a web-site (www.cmps.gov.uk/policy hub), including a workbook Using International Comparisons in Policy Making. The rationalisation is as follows:

Looking abroad to see what other governments have done can point us towards a new understanding of shared problems; towards new solutions to those problems; or to new mechanisms for implementing policy an improving the delivery of public services. International examples can provide invaluable evidence of what works in practice, and help us avoid either re-inventing the wheel or repeating others' mistakes (CMPS, 2002)

This is a form of the ‘internationalisation of policy’ but one that internalises lessons to a national system. However, while the CMPS advocates the possibilities for improved policy development, the interest within other parts of the civil service to engage in rigorous international comparison is subject to debate.

Some parts of the bureaucratic structure are more attuned to policy transfer (Berry \& Berry, 1999: 179). This may result from numerous factors: the presence or not of an international

professional (or epistemic) community; resourcing issues and time constraints in policy 
development; political sensitivities as well as an individual or organisational disinclination to look elsewhere. Many examples of 'best practice' may exist and may be advocated inside and outside a social system, but ignored.

Where CMPS has tried to inculcate a bureaucratic proclivity for lesson-drawing, other state agencies are involved in the export of policy knowledge and 'best practices'. The International Development Research Center (IDRC) in Canada is a good example. IDRC is a quasiautonomous government development agency with the objective of helping communities in the developing world find solutions to social, economic, and environmental problems through research (www.idrc.ca). Although a 'small fish' in the donor community pond, nevertheless IDRC projects contribute to the 'internationalisation of development policy' by externalising lessons. For example, a core objective of RITC (research for international tobacco control), a secretariat based at IDRC, is 'knowledge transfer' to support local, national and international policy-making to prevent, reduce and contain smoking (http://archive.idrc.ca/ritc/en/index.html; also Studlar, 2004).

One IDRC Ukranian project is replete with examples of transfer dynamics; specifically, negative lesson-drawing, emulation combined with learning as well as resistance to imposed normative standards. This project was focused on the Dnipro River Basin and major components were water pollution control, bioassays of water toxicology, information systems development and environmental auditing. A tangible example of transfer was the visit to Canada of a team of Ukrainian 'environmental entrepreneurs' to view Toronto waste management practices. According to participants, "it was better to see once than to hear many times" (Anon, 2002: 28). The visit was a mechanism to appreciate the technology (the hardware) but also the ideas and informal practices (software) of Canadian environmental management. 
IDRC technique style of development assistance was seen in a positive light as facilitating informed adoption of 'best practice'. Copying or mimicry of policy or the imposition of policy lessons provides less scope for learning or the development of consensual knowledge. A frequent complaint of many developing country experts is that of the lack of the local knowledge of foreign consultants and one-size-fits-all approach to economic reform. Indeed, the evaluators of the Ukranian project noted that other donor programs where " $90 \%$ of work is implemented by foreign experts” leads to less potential for learning and extent of transfer. This contrasts with the willingness of IDRC to share information and facilitate data exchange (Anon, 2002: 15). More specifically, the stable relationship with IDRC helped cultivate an understanding of the need to adopt international standards rather than pursuing with a dual system of reporting to the donor and separate mode of environmental reporting to Ukrainian authorities. Importantly, IDRC project culture enabled local researchers to i) acquire knowledge to prepare competitive project proposals; ii) learn the language of donors; and iii) enter the international scientific community.

A case of conscious 'non-transfer' or 'negative lesson-drawing' took place when IDRC refused to fund an expensive 'technological fix' (a high-energy plasma to treat waste from a meat processing plant) sought by local Ukrainian scientists and managers. IDRC position was that the plasma-based equipment was not only expensive but impractical (Anon, 2002: 32) for local needs.

An explicit form of normative transfer concerned the requirement of reporting on gender representation and participation in IDRC projects. It was met with some resistance as well as a lack of comprehension regarding the requirement for women's involvement as 'imposed by the IDRC's agreement with the Government of Canada'. In the main, Ukranian partners 'remained skeptical', did not see gender participation in senior decision making as a priority issue and ‘denied the existence of a problem’. In many quarters, gender requirements were seen as an issue 
inappropriately 'imported from abroad' (Anon, 2002: 44-45). Gender reporting took place but it was done for tactical reasons and not as a consequence of learning.

One tendency in the policy transfer studies is the emphasis on investigating directly observable transfers of people, policy instruments or legislation. There is relatively little analysis of the transform of norms. Implicit in IDRC funding priorities and reporting requirements for projects are certain normative standards. Norms are being transferred (if not necessarily absorbed) regarding research standards and gender participation. There was local receptiveness to scientific norms but not to gender issues. This suggests that the degree of transfer is likely to be more shallow or superficial when it is imposed and/or when little local learning is involved. Norms related to gender needed to be 'endogenised' to the same level of acceptance as IDRC programme officers specifically, and Canadian society generally, before they could make sense within the Ukranian community.

Relatedly, transfer is more likely to occur when lessons are 'proximate'; that is, transferred from a jurisdiction that is geographically, ideologically or culturally proximate. For instance, the 'transplanting' in the 1960s and 1970s of Anglo Westminster parliamentary systems to the South Pacific was, in some degree, incompatible with indigenous institutions. The exporting and importing systems were not proximate. Many of these small states lacked strong local legal expertise undermining implementation of constitutions. Additionally, the 'transferability of a constitution will be determined by the presence or absence of an appropriate Grundnorm ... the political preconditions, the mobilisation of political forces, and settlements between political groups” over land, ethnic representation before institutions 'stick' (Larmour, 2002: 49). By contrast, in Europe there is some semblance of a common cultural heritage, shared histories, languages and institutions as well as similar levels of economic and political development. 


\section{Transfers from International Organisation}

International organisations like the OECD or the United Nations (UN) are means to help develop common policy responses in some fields. Likewise, international regimes - a set of similar norms and principles, rules and decision-making procedures around which actor expectations converge - can also lead to harmonisation. UNAIDS, for example, is a multilateral initiative to co-ordinate responses to this pandemic. The establishment of UNAIDS may well reflect the institutionalisation of epistemic communities and embedded 'consensual knowledge' about not only the causes of the pandemic but also of a range of necessary international and domestic policy responses.

As is evident, the European Union (EU) is an important institution promoting convergence of member states around policies such as the Euro. Harmonisation has been propelled by the recognition of states of interdependence and the benefits of membership and aided with economic and political incentives: structural funds, cohesion funds, voting rights, and assistance for fledgling democracies. Despite some sacrifice of national autonomy, harmonisation has been bolstered by awareness of the costs of divergence. Following earlier concepts of diffusion patterns, all four types are evident in the EU context. First, in many policy areas there are communication networks among officials (Radaelli, 2000). Second, states are influenced by geographically proximate neighbouring states as is evident from the number of states applying for accession. Thirdly, leader states pioneer the adoption of a policy that some 'laggard' states subsequently follow. For instance, candidate countries emulate EU standards prior to accession. Fourthly, the European Commission is a vertical influence for compliance through directives and regulations. Numerous studies of Europeanisation now exist (Future Governance at: http://www.hull.ac.uk/futgov/). In its external relations the EU is also a transfer agent. In preparation for the eastern enlargement of the EU, there are three pre-accession instruments available to the 
ten candidate countries. Collectively, they are designed to help induct the candidate countries into both the norms and technical arrangements of the EU regional policy model.

The Organisation for Economic Cooperation and Development also acts as a transfer agent. An example is the information disseminated by the OECD's Public Management Programme (PUMA: http://www1.oecd.org/puma/). It builds a number of mechanisms - publications, networks of senior officials, conferences, etc. - to spread information and provide 'forward thinking' on matters such as national accounting standards, human resources management and 'OECD Best Practices for Budget Transparency’. Similarly, a joint initiative of the EU and OECD - SIGMA, Support for Improvement in Governance and Management in Central and Eastern Europe: http://www1.oecd.org/puma/sigmaweb/ - advises transition countries on improving public governance at the central government level.

The development and spread of economic norms - such as transparency, capital mobility, convertibility and inflation avoidance - also influences state behaviour and conformity to what has been called the 'liberal international economic order' (Lal, 2001: 237) or more recently, the (post) 'Washington Consensus'. Shared norms precede convergence in the case where there is a common 'cosmological heritage' (Lal, 2001: 241). Convergence has been facilitated by at least three sets of economic (dis)incentive: (i) treaties concerning trade as well as the international property rights of foreign capital; (ii) status incentives derived from joining economic clubs such as the World Trade Organization (WTO) or EU; and (iii) economic sanctions or new forms of economic conditionality tied to loans. Without a 'cosmological heritage' or 'shared norms' that shape collective behaviour, compulsion is often necessary to ensure compliance and convergence. Economic sanctions are a blunt instrument and have been substantially criticised for being ineffective and/or having perverse outcomes. Conditionality has five features relevant to understanding coercive and cajoled modes of policy transfer (Lal, 2001: 253-56). 
1. Inducement: getting governments to enact policies they otherwise would not have initiated;

2. Selectivity: aid given only to those countries already exhibiting a 'good' policy environment;

3. Paternalism: donors attempt to get aid spent on the goods and services that they favour;

4. Restraint: seeking protection against policy reversal that may occur with a new government. It differs from inducement in that there is no policy disagreement between the recipient and donor country;

5. Signalling: Aid is used a device to signal 'good' policy behaviour by the recipient country

Inducement has lead to recipient states exaggerating the cost of policy reform thus raising the 'price' of aid, as well as selling the same reform package more than once to multilateral agencies (Lal, 2001: 253-56). Such evidence suggests that bribing the 'unconvinced' is unlikely to work. By contrast, a system of tied aid that 'locks-in' reform is more likely to reward 'good' performers and penalise countries with poor policy records. It is a policy transfer strategy that "creates incentives for the 'bad' to emulate the 'good' in the hope of getting future foreign aid” (Lal, 2001: 255).

Coercion is not the only (or even favoured) approach of international organisations to promote 'best practice' or adherence to international standards. Institutions such as the World Bank, WTO and IMF have set up research departments or hold conferences and consultations to advocate the 'scientific' validity of their objectives, and have engaged in various outreach 
activities, data gathering and monitoring to promote awareness and educate the public. In this way they can become one institutional junction for epistemic communities.

Knowledge sharing is a strategy of the World Bank and is based on the view that knowledge (education, technical expertise, IT, knowledge management, etc) plays a central role in economic and institutional development. It includes grandiose initiatives such as the Development Gateway; a common portal and one-stop shop for development knowledge on the Internet with one objective to 'harmonise' multiple different databases on development activity (King, 2002). The World Bank Institute (WBI) promotes sharing and induction into economic norms through developments such as two 'spin-off' organisations - the Global Knowledge Partnership and Global Development Network (GDN) - as well as its Distance Learning programme, the Learning and Leadership Center and the Training Institutes. The Bank presents itself as an agent of learning and a prompt for lesson-drawing: "the world's nations can learn a great deal from each other’s experience” and “... we will continue to facilitate this learning” (EDI, 1998: 2). The Bank does not simply 'diffuse’ knowledge; it also helps create new organisations like the GDN or other policy partnerships - to synthesise and tailor such knowledge into products and 'best practice' that is then marketed and advocated. However, there are significant impediments: “... in the view of several senior (Bank) managers, there remains a serious and growing gap between what people are describing as best practice and the extent to which these ideal practices can be built into operations” (King, 2002: 319 my inclusion).

Transfer also occurs between international organisation. For example:

The WTO’s establishment was not just intended to formalise, deepen and widen an international system of trade regulation. It was also to bring greater coherence in global economic policy making by drawing together the work of the WTO with that of the International Monetary Fund (IMF) and World Bank, as well as to 
develop relations with other bodies such as the World Intellectual Property Organization (WIPO), the International Telecommunications Union (ITU) and the International Organization of Standards (IOS) (Wilkinson, 2002: 129).

Indeed, at the time of writing, 'harmonization' among development organisations and donors was specified as a 'hot topic' on the World Bank' agenda (go to: http://www.aidharmonization.org/). Integration among international organisation creates “overlapping clubs” and a means to provide “order” and policy co-ordination (Rosecrance \& Stein, 2001: 232). In other words, sustained interaction at institutional and professional levels amongst these international organisations creates policy spaces in which policy transfers can also occur. As discussed below, one type of ‘club’ is a global public policy network. They represent a further form of the 'internationalisation’ of policy making. But they may also herald something more; that is, new forms of authority and global policy making.

\section{Non-State Actors}

The diffusion of policy ideas, expertise, programmes and personnel from NGOs and social movements can be extensive. A novel development in this regard is the International Simultaneous Policy Organisation, an international NGO advocating the harmonisation of legislation between countries to 're-regulate global financial markets and transnational corporations' (www.simpol.org). Here again, a problem of terminology arises: 'Policy transfer' directs analytical gaze towards the state when it may be that ideas, behaviours, perceptions and discourses which are transported and adapted irrespective of state structures. As indicated, nonstate actors in transnational advocacy networks may be better at the 'soft transfer' of broad policy ideas (Evans \& Davies, 1999; Keck \& Sikkink, 1998) influencing public opinion and policy agendas. TANs give 'normative resonance' to cause groups by pulling together the symbols, language and 'cognitive frames' that portray 'morally compelling' issues in a concrete manner to 
which the public can respond. By contrast, officials are more involved in 'hard' transfer of policy practices and instruments involving formal decision-making, legislation and regulation.

Some non-state actors are 'policy transfer entrepreneurs' (Dolowitz \& Marsh, 1996: 345) facilitating exchanges between actors in several countries at any one time. Think tanks or research institutes, consultancy firms, philanthropic foundations, university centres, scientific associations, professional societies, training institutes and so forth help transfer the intellectual matter that underpins policies. Ordinarily private or quasi-autonomous organisations, many have used their intellectual authority or market expertise to reinforce and legitimate certain forms of policy or normative standards as 'best practice'. As indicated in the three examples below, they provide essential services for decision-makers by acting as resource banks; advocating policy ideas and developing discourses of transfer; as well as spreading ideas and information through their professional networks and into media and civil society.

Transnational Think Tanks: The think tank form is an organisational object of transfer that has been transplanted to many developing and transition countries by bodies such as Freedom House, USAID and the World Bank. But cross-national comparison is also part of their modus operandi. A more recent example of research institutes roles in knowledge/policy transfer is the Global Development Network (www.gdnet.org). At the launch of the GDN, former World Bank Chief Economist, Joe Stiglitz', stated that “in developing countries, think tanks have proliferated and have become important agents to introduce and adapt new policy initiatives” (1999: 9). Similarly, Eastern and Central Europe is an area of significant think tank growth in the past decade and where the exchange of ideas, policy and practice is dense (Struyk, 2002). The Open Society Institutes have been an important medium for, and mediator of, Western ideas for transition. Another example, the Evian Group (www.eviangroup.org) educates and advocates the benefits of a liberal trading order. Based in Switzerland, and in orbit around the WTO, it is an 
elite association of corporate, academic and government leaders who are broadly aligned in a normative project to instill in public and political consciousness the virtues of an open world economy.

Multinational Consultants: Consultancies have contributed to the globalization of the core values of Western culture generally, and the transmission of the idea of liberalisation specifically. Often the global brand name of consultant firms act as 'reputational intermediaries'. They legitimate and signal to a wider international audience of investors and financial institutions that a country is a "prudent economic manager", "that the right kind of people are involved in the process" and who "understand the global standards and are in compliance” (Nesseth, 1999: 22; also Orenstein, 2003: 177). Democracy promotion is also big business with the rise of 'political campaign consultants' selling their expertise concerning election campaign practices in democratising countries such as El Salvador, Brazil and Chile and in Europe, Bulgaria, Hungary, Malta, Spain and Turkey. These consultants are sufficiently numerous to organise themselves into professional bodies such as the International Association of Political Consultants and the World Association of Public Opinion Research (Bowler \& Farrell, 2000). With the advent of managerialism and its stress on exploiting the tools of financial management for efficient government, political executives and the senior officials of management consultancies increasingly interact in venues such as PUMA (Krause Hansen et al, 2002). The 'new public management' (NPM) was spread around the globe because of the existence of a global 'fashionsetting' network of management consulting firms and growth in the use of external consulting services by governments (Saint Martin, 2000). The large consulting firms such as PriceWaterhouseCoopers, KPMG or Andersen Consulting established 'government consulting divisions' advocating the adoption of 'a more managerial approach in government'. Consulting firms were provided enormous opportunities by rapid changes in information technology, down- 
sizing and out-sourcing, as well as the political transformations and move towards market economies in the former soviet states (Deacon et al, 2003: 154).

International Foundations: Political foundations are quasi-governmental actors that tend to provide support to political parties (as in the case of the German Stiftungen) or incumbent governments. For instance, the British Westminster Foundation for Democracy has been proactive in exporting democracy (Scott, 1999). Independent foundations, by contrast, have a greater degree of autonomy by virtue of their financial independence. However, they are equally involved in the transnational spread of ideas, values and norms. There has been a long history of foundations promoting Western norms and standards. The international programs of the American foundations have been especially important in the diffusion of American style practices to other countries (see Parmar, 2002 and the 'Foundations of Globalisation’ conference at: http://les.man.ac.uk/government/foundationsofglobalization.htm).

Knowledge organisations transfer knowledge and people. In theory, they have the institutional capacity to scan the international environment and undertake detailed evaluations of policy that will help prevent the simplistic, ad hoc copying of policy that leads to inappropriate transfer and policy failure. However, it is difficult to generalise about the character of lessons drawn by knowledge organisations (or the actors in them) and whether learning has taken place. The capacities and intentions of these actors differ considerably and will shape the interpretations of policy experience, which lessons are drawn and how and why they are 'exported' or 'imported'. Notwithstanding evidence of considerable degree of information sharing, policy research and expert advice, the causal nexus between transferred policy ideas and their adoption is not clear and transparent. There are many intervening variables.

It is relatively easy to engage in the 'soft' transfer of ideas and information but it is a more difficult enterprise first to see such ideas structure thinking and secondly, to ensure that ideas 
institutionalised. While some ideas may capture the political imagination, many more fall by wayside. Non-governmental modes of knowledge transfer are more extensive than policy transfer. The non-governmental status of non-state organisations is a major structural constraint to policy transfer. Non-state actors cannot bring about policy transfer alone but are dependent on governments and international organisations to see policy transfer instituted. Accordingly, these organisations are often to be found in partnership or coalition on either an ad hoc or more permanent basis with government departments and agencies, international organisations or with other NGOs.

\section{Policy Partnership and Transfer Networks}

This paper is concerned less with current debates as to whether policy transfer is on the increase (Orenstein, 2003: 184) and determined more to widen understanding on two other fronts. Firstly, to broaden cognition of the potential domains where policy transfer takes place from its horizontal intergovernmental focus to vertical supra-national policy venues indicative of multilevel governance. In this regard it is distinctive from some IR analyses that also suffer from methodological nationalism when they seek to explain norm diffusion in terms of its impacts on domestic politics (Checkel, 1997). Secondly, to extend the range of who (or what) engages in policy transfer to include transnational actors and structures such as global networks. In this regard, key players are epistemic communities that create and disseminate specialised policy knowledge and transnational advocacy networks (TANs). Yet, these networks are outsiders to decision-making compared to the insider status and official links of 'global public policy networks'.

The involvement of non-state actors in certain fields of policy making and policy delivery can lead to the 'transnationalisation of policy'. In other words, policy development is not the exclusive prerogative of government or international organization (or NGOs acting on their 
behalf) but incorporates independent societal and corporate interests into a policy network. Transnational policy communities of experts and professionals share their expertise and information and form common patterns of understanding regarding policy through regular interaction (international conferences, government delegations and sustained communication) (Bennett, 1991: 224-25). Accordingly, a more dynamic perspective on transfer is to recognise the joint interactions between states, international organisations and non-state actors. These interactions can involve a shared experience of learning about problems and the development of a common perspective or “international policy culture” (Ikenberry, 1990: 89).

\section{Global Public Policy Networks}

Networks are increasingly being cultivated governments and international organisations for the delivery of public goods. In many issue areas, governments and international organizations no longer have the ability to design and/or implement effective public policies. Treaties and conventions are often too slow for immediate issues. 'Global public policy networks' (GPPNs) are helpful in some issue areas to come to terms with these challenges. Examples include the ISO 14000 process, the Consultative Group on International Agriculture Research, the Global Water Partnership and the 'Roll Back Malaria Initiative' (Reinicke \& Deng 2000; see www.globalpublicpolicy.net). They have sustained official involvement with a multiplicity of non-state actors, international organisations and states with an interest in a specific policy area. Their rising number suggests a shift in the locus of policy debate and content away from formal global institutions like the UN (Deacon et al, 2003: 28). Nevertheless, GPPNs may be thought of as quasi-official vehicles for policy transfer.

GPPNs are distinguishable from epistemic communities and transnational advocacy networks - all of which overlap to some degree depending of the policy issue. However, TANs can be more clearly considered as a 'de facto' mode of global governance and transfer. TANS are 
about agenda setting and advocacy. GPPNs also act as advocates but are more institutionalized, act with a greater degree of what might be called 'delegated authority' given their political patronage, and are directly involved in resource allocation and policy delivery. A transnational advocacy network is also a much broader collectivity than an epistemic community. Theorists of epistemic communities exclude activist groups stressing the scientific credentials of members of a community, their defining 'consensual knowledge' and their involvement in highly technical issues (Haas \& Haas, 1995). However, epistemic communities are not static. In some circumstances, they can dissolve into a GPPN. This is especially the case given that "knowledge hardly ever remains consensual once it passes out of the control of the initiating epistemic community" into the hands of a national or international bureaucracy (Haas \& Haas, 1995). Similarly, epistemic communities can act in conjunction with transnational advocacy networks (Keck \& Sikkink, 1997: 134, 161). Unlike GPPNs, neither TANs nor epistemic communities are governance structures.

Notwithstanding these differences, a key feature of a network is a shared problem on which there is an exchange of information, debate, disagreement, persuasion and a search for solutions and appropriate policy responses. Networks are a framework for policy oriented learning (Bennett, 1991: 224). They represent a soft, informal and gradual mode for the international dissemination of ideas and policy paradigms. Through networks, participants can build alliances, share discourses and construct the consensual knowledge that defines an international policy community. Networks also enable actors to operate beyond their domestic context and networks are the means by which organisations individually and in coalition can project their ideas into policy thinking across states and within global or regional forums.

Networks can also be viewed as mechanisms for 'hard' transfers, especially in GPPNs. That is, a mode of governance - regulation, policy coordination, pooling of authority and joint 
decision-making - whereby the patterns of linkages and interaction as a whole are taken as the unit of analysis, rather than simply analysing actors within networks. This approach focuses on the structure and processes through which joint policy is organised. In short, there is a functional interdependence between public and private actors whereby networks allow resources to be mobilised towards common policy objectives in domains outside the hierarchical control of governments (Börzel, 1998).

It is a view of policy transfer as having 'steering capacities' to become a form of 'governance by diffusion’ (Jörgens, 2001). Indeed, a key function of global networks is facilitating the negotiation and settlement of global standards. This is happening in areas as diverse as financial regulation and environmental management. The complexity of negotiating and setting standards, as well as the concerns of fairness and equity, typically requires the involvement of stakeholders from all sectors on a representative basis. However, they lack the 'de jure' authority of states and international organisations.

An example of a GPPN is GAVI; the Global Alliance on Vaccination and Immunization (www.vaccinealliance.com). It is a coalition of UN organizations, national governments, foundations, NGOs, and the pharmaceutical industry, formed in response to stagnating global immunization rates and widening disparities in vaccine access among industrialized and developing countries. The core of GAVI business, to-date, has been to introduce new vaccines to countries but it is also an important structure for the dissemination of knowledge about vaccines. However, successful standard setting does not end with agreement on a norm. The network must also proceed to implementation and compliance. In terms of standards setting, GAVI has been praised for introducing across countries, results based funding systems in the health area as well as encouraging parallel reporting and monitoring systems (Deacon et al, 2003: 49-54). In addition to establishing common procedures, GAVI itself has been used as a model for the establishment 
of other health related GPPNs such as the Global Fund to Fight Against AIDS, Tuberculosis and Malaria, and the Global Alliance for Improved Nutrition (GAIN). Rather than a model for countries to emulate, GAVI and other GPPNs provide models for transnational network entrepreneurs. However, the long term sustainability of these networks (especially receipt of promised donor support) casts doubts about network capacities to compel or cajole compliance and underscores their 'de facto’ governance status.

The advantage of focusing on these kinds of networks is two fold. First, as discussed above, these coalitions provide insight into policy transfer at transnational levels. Secondly, a focus on networks is one approach to reconciling agent-centered policy transfer approaches with the structurally oriented diffusion/convergence studies. Networks can be viewed as agents of transfer but also as structures. Table 1. plots how networks as transfer mechanisms differ from, but also combine elements of the ideational and institutional mechanics of transfer.

These three modes of transnational transfer are not mutually exclusive. Indeed, it is conceivable that some GPPNs could 'harden' and institutionalise over time to become more formal institutions with political authority. Some critics claim that these 'independent' GPPNs circumvent the governing authority and standard setting function of UN or WHO (Deacon et al, 2003: 57). Consequently, there have also been suggestions that as GPPNs tend to be issue focused, pragmatic in orientation and sub-contracted, there needs to be an over-arching sets of principles to steer the conduct of these (privatised) policy arrangements and ensure some accountability (Deacon et al, 2003: 29).

\section{Reprise: Transnational Spaces of Governance}

The objective has been to shift the focus from institutions and policies at the nation-state level, to address how policy transfer not only takes place in international domains but can also be 
considered one constitutive element of transnational governance. This is not to deny the continuing power and impact of nation-states. The domestic politics of nation states will continue to ensure difference and diversity. States will remain important mediators of globalisation but their capacities to react and respond will differ substantially.

However, the transfer of policies, administrative arrangements, institutions and ideas happens within regional associations, between international organisations and is integral to networks. Circumstances of complex multilateralism bring additional considerations of how nonactors by-pass national policy making processes to influence international organisations. This paper has neither sought to provide a comprehensive overview of the transfer activities of institutions like the World Bank, IMF, the EU or WTO nor simply redress the insufficient attention given to their civil society partners. Instead, the concern has been to indicate that transfer activity transcends both the national and the international and also takes place 'in the spaces within and between these overlapping and competing agencies' as 'something that passes for a global governance mechanism' (Deacon et al, 2003: 15-16). One consequence is the 'transnationalisation of policy'. 


\section{References}

Anon. (2002) 'Environmental Management Development in Ukraine and its Influence on Public Policy’, Report prepared for the Evaluation Unit of IDRC, Canada, International Development Research Centre.

Bennett, Colin. J. (1991) 'Review Article: What is Policy Convergence and What Causes It?' British Journal of Political Science, 21: 215-233.

Bennett, Colin. J. and Howlett, Michael. (1992) 'The lessons of learning: Reconciling theories of policy learning and policy change’, Policy Sciences, 25(3): 275-94.

Berry, Frances Stokes. and Berry, William. D. (1999) 'Innovation and diffusion models in policy research', in Paul A. Sabatier. (ed) Theories of the Policy Process, Boulder CO., Westview Press.

Blyth, Mark. (2002) Great Transformations: Economic Ideas and Institutional Change in the Twentieth Century, Cambridge, Cambridge University Press.

Börzel, Tanja. (1998) “Organizing Babylon -- on the different conceptions of policy networks”, Public Administration, 76 (summer): 253-73.

Bowler, Shaun and Farrell, David. (2000) “'Americanization' By Example: the Internationalization of Election Campaign consultancy”, in James Thurber (ed.) Campaign Consultants in Election Campaigns. Washington DC: Brookings Press, 2000, $153-74$. 
Checkel, Jeffrey. (1997) 'International Norms and Domestic Politics: Bridging the rationalistConstructivist Divide’, European Journal of International Relations, 3(4): 473-95.

CMPS - Centre for Management and Policy Studies (2002) Using International Comparisons in Policy Making: Toolkit, Cabinet Office.

Deacon, Bob., Ollila, Eeva., Koivusalo, Meri. And Stubbs, Paul. Eds. (2003) Global Social Governance: Themes and Prospects, Helsinki, GASPP.

Dolowitz, David. (1997) 'British Employment Policy in the 1980s: Learning from the American Experience', Governance, 10 (1):

Dolowitz, David. \& Marsh, David. (2000) "Learning From Abroad: The Role of Policy Transfer in Contemporary Policy Making”, Governance 13 (1): 5-24.

Dolowitz, David. \& Marsh, David. (1996) 'Who Learns from Whom: A Review of the Policy Transfer Literature’, Political Studies, 44(2): 343-57.

Drezner, Daniel. W. (2001) 'Globalization and Policy Convergence’, International Studies Review, . 3 (1): 53-78.

EDI - Economic Development Institute (1998) The World Bank Economic Development Institute 1998 Annual Report, Washington DC., World Bank. 
Evans, Mark. and Davies, Jonathon (1999) 'Understanding Policy Transfer: A Multi-level, Multidisciplinary Perspective’, Public Administration, 77(2): 361-385.

Haas, Peter. M. \& Haas, Ernst. B. (1995) 'Learning to Learn: Improving International Governance’, Global Governance, 1 (3): 255-285

Hall. Peter (1993) 'Policy Paradigms, Social Learning and the State: The Case of Economic Policy making in Britain’, Comparative Politics, 25: 275-97.

Ikenberry, G. John. (1990) 'The International Spread of Privatization Policies: Inducements, Learning and 'Policy Band wagoning', in E. Suleiman \& J. Waterbury (eds.) The Political Economy of Public Sector Reform and Privatization, Boulder: Westview Press.

Jörgens. Helge. (2000) 'The Diffusion of Environmental Policy Innovations - Preliminary Findings from an International Workshop', 'Diffusion of Environmental Policy Innovations’, Berlin, 8-9 December.

Keck, Margaret, and Sikkink, Kathryn (1998) Activists Beyond borders: Advocacy Networks in International Politics, Ithaca NY., Cornell University Press.

King, Kenneth. (2002) 'Banking on Knowledge: the new knowledge projects of the World Bank', Compare, 32(3)311-26. 
Krause Hansen, Hans., Dorte Salskov-Iversen and Sven Bislev (2002) 'Transnational Discourse Communities: Globalizing Public Management’ in Richard Higgott \& Morten Ougaard (eds) Understanding the Global Polity, London, Routledge.

Lal, Deepak. (2001) ‘The development and spread of economic norms and incentives’, in Richard Rosecrance and Arthur A. Stein (eds.) The New Great Power Coalition: Toward A World Concert of Nations, Lanham, Rowman and Littlefield Publishers.

Larmour, Peter. (2002) 'Westminster Constitutions in the South Pacific” A 'Policy Transfer' Approach’, Asian Journal of Political Science, 10(1): 39-54.

Nesseth, Hans. (1999) 'Constructing Authority in the Global Political Economy: Global Consultancy and Financial Liberalization in Indonesia', paper prepared for the Annual Meeting of the International Studies Association, Washington DC. February 16-20.

Ogden, Jessica., Walt, Gill, \& Lush, Louisiana. (2003) 'The politics of 'branding' in policy transfer: the case of DOTS for tuberculosis control', Social Science and Medecine, 57: 179-188.

Orenstein, Mitchell. (2003) ‘Mapping the Diffusion of Pension Innovation’ in Robert Holzmann, Mitchell Orenstein, and Michal Rutkowski (eds.) Pension Reform in Europe: Process and Progress. Washington, DC: The World Bank.

Parmar, Inderjeet. (2002) 'American Foundations and the Development of International Knowledge Networks', Global Networks, 2(1): 13-30 
Radaelli, Claudio. (2000) "Policy Transfer in the European Union: Institutional Isomorphism as a Source of Legitimacy, Governance, 13 (1): 25-44.

Reinicke, Wolfgang. \& Deng, Francis (2000) Critical Choices: The United Nations, Networks and the Future of Global Governance, executive summary, available at: www.globalpublicpolicy.net/

Rose, Richard. (1993) Lesson Drawing in Public Policy: A Guide to Learning Across Time and Space, Chatham, N.J., Chatham House.

Rosecrance, Richard. \& Stein, Arthur. A. (2001) 'The theory of overlapping clubs', in Richard Rosecrance and Arthur A. Stein (eds.) The New Great Power Coalition: Toward A World Concert of Nations, Lanham, Rowman and Littlefield Publishers.

Sabatier, Paul. (1991) 'Political Science and Public Policy', PS: Political Science and Politics, 24(2): 144-156.

Saint-Martin. Denis (2000) 'The Formation of the New Entrepreneurial State and the Growth of Modern management Consultancy', in Dietmar Braun \& Andreas Busch (eds.) Public Policy and Political Ideas, Cheltenham, Edward Elgar.

Scott, James. (1999) “Transnationalizing Democracy Promotion: The Role of Western Political Foundations and Think-Tanks”, Democratization, 6(3):146-170. 
Schneider, Anne. \& Ingram, Helen. (1988) 'Systematically Pinching Ideas: A Comparative Approach to Policy Design', Journal of Public Policy, 8(1): 61-80.

Stiglitz, Joseph. (2000) 'Scan Globally, Reinvent Locally: Knowledge Infrastructure and the Localization of Knowledge', in D. Stone (ed.) Banking on Knowledge: The Genesis of the Global Development Network, London, Routledge.

Struyk, Raymond. J. (2002) 'Transnational think tank networks: purpose, membership and cohesion', Global Networks, 2(1): 83-90.

Studlar, Donley. (2004) ‘Tobacco Control Policy Instruments in a Shrinking World: How Much Policy Learning ?’, in Eran Vigoda and David Levi-Faur, eds. International Public Policy and Management: Policy Learning and Policy Beyond Regional, Cultural, and Political Boundaries, New York: Marcel Dekker.

Wilkinson, Rorden. (2002) ‘The World Trade Organization’, New Political Economy, 7(1): 12941. 
Word count: 8421

\author{
Diane Stone \\ Center for Policy Studies \\ Central European University \\ H-1051 Budapest \\ Nador utca 9 \\ Hungary \\ $\underline{\text { Stone@ceu.hu }}$
}

\begin{abstract}
Diane Stone is Marie Curie Chair and Co-Director of the Center for Policy Studies at the Central European University. She is on leave from the Department of Politics and International Studies, University of Warwick. Other research interests include knowledge institutions, policy networks and think tanks.
\end{abstract}

